\title{
A grid-like incised pattern inside a Natufian bedrock mortar, Raqefet Cave, Israel
}

\author{
Dani Nadel ${ }^{1}$, Danny Rosenberg ${ }^{2}$ \\ 1. Zinman Institute of Archaeology, University of Haifa, Mount Carmel, 3498898 Haifa, Israel. \\ Email: dnadel@research.haifa.ac.il \\ 2. Laboratory for Ground Stone Tools Research, Zinman Institute of Archaeology, University of Haifa, Mount \\ Carmel, 3498898 Haifa, Israel. Email: drosenberg@research.haifa.ac
}

\begin{abstract}
:
Bedrock features are a hallmark of the Natufian (ca. 15,000-11,500 cal BP) in the southern Levant and beyond and they include a large variety of types, from deep variants to shallow ones and from narrow mortars to wide basins. They are usually interpreted as food preparation facilities, associated with Natufian intensification of cereal and acorn consumption. However, inside the shaft of one deep narrow Natufian mortar at the entrance to Raqefet Cave (Mt. Carmel, Israel), we found a set of grid-like incisions accompanied by irregular lines. This pattern is similar in the general impression and the details of execution to incised stone slabs and objects found in other Natufian sites. As in several other Natufian objects, the incised patterns were hardly visible at the time, due to their light appearance and concealed location. The engraving act and symbolic meaning of the contents were likely more important than the display of the results. Furthermore, the Raqefet mortar was incorporated in a structured complex that also included a slab pavement and a boulder mortar. Thus, the complex motif, the specific feature it was carved on (inside a deep mortar), the associated features, and the location at the entrance to a burial cave all suggest an elaborate ceremonial and symbolic system.
\end{abstract}

Keywords: Natufian; incised patterns; bedrock mortars; ground stone tools; Raqefet Cave

\section{Introduction}

The Natufian culture (ca. 15,000-11,500 cal BP) in the southern Levant has long been the focus of a range of studies owing to its cultural-historical position, with semi-sedentary complex hunter-gatherer groups standing on the threshold of agriculture (e.g., Garrod 1957; Bar-Yosef 1983; 2002; Bar-Yosef \& Belfer-Cohen 1989; 2002; Byrd 1989; Henry 1989; 1995; Belfer-Cohen 1991a; Valla 1995; Weinstein-Evron 1998; 2009; Belfer-Cohen \& BarYosef 2000; Hayden 2004; Boyd 2006). Subsistence patterns included hunting and foraging. Burials in or near dwellings and in separate, distinct burial grounds are one of the key features of this culture and, to date, several hundred Natufian burials are known, mainly from the Mediterranean southern Levant (e.g., Garrod \& Bate 1937; Wright 1978; Bar-Yosef 1981:

Published by the School of History, Classics and Archaeology, University of Edinburgh ISSN: 2055-0472. URL: http://journals.ed.ac.uk/lithicstudies/

This work is licensed under a Creative Commons Attribution 2.5 UK: Scotland License. 
401, 1983; Belfer-Cohen 1988; Perrot \& Ladiray 1988; Byrd \& Monahan 1995; Murail et al. 2001; Bocquentin 2003). Burials are particularly interesting when social aspects and ritual issues are addressed, and in this context, material remains from graves have been thoroughly discussed (e.g., Wright 1978; Byrd \& Monahan 1995; Bocquentin 2003). Natufian ground stone tools are notable, reflecting intensive production and high quality finishing (e.g., Wright 1991; 1994; Rosenberg et al. 2012; Rosenberg \& Nadel 2014); when found in burial context they appear to reflect upon their particular importance in both mundane and spiritual life.

Bedrock features, as a component of the ground stone industry, are a hallmark of the Natufian in the southern Levant and beyond (Nadel \& Lengyel 2009; Nadel \& Rosenberg 2010; 2011). These are found in all ecological settings and in some sites they are found in large numbers regardless of bedrock type (e.g., basalt, limestone, sandstone). Furthermore, similar features are carved in boulders and slabs (Rosenberg \& Nadel 2014). However, in some sites bedrock features and boulder mortars are rare or absent. At Raqefet Cave there are about 100 bedrock features, previously discussed in the literature (Nadel \& Lengyel 2009; Nadel et al. 200; 2009b; 2013). Yet, one deep mortar (C-XVIII) differs from all the others, as it has a grid-like pattern incised inside its shaft. As far as we know, it is the only Natufian mortar with incised patterns hidden inside the shaft. The goals of this paper are to characterize the mortar and its setting, describe the incised patterns, and discuss some implications in light of similar patterns found on stone slabs in other Natufian sites.

\section{Natufian incised objects}

The Natufians are well-known for their artistic creations in a range of raw materials and realms, all indicating innovative approaches to the use of objects in their symbolic world (e.g., Garrod 1957; Belfer-Cohen 1988; 1991a; 1991b; Bar-Yosef \& Belfer-Cohen 1999; BelferCohen \& Bar-Yosef 2009; Shaham \& Belfer-Cohen 2013 and references therein). Although the Natufians were not the first in the region to incorporate art and symbolic manifestations, earlier Epipalaeolithic objects are rare and in many ways unique (e.g., only isolated examples of each type or pattern were found). Noteworthy is the small engraved pebble from Urkan aRub IIa (Hovers 1990). On one face are several sets of elongated lines, with small ladder-like incisions between a pair of long lines. On the opposite face there are also two ladder-like sets, but a large portion of the face is covered by a grid-like pattern; there are also long isolated diagonal lines and sets of dense short lines (Hovers 1990: figs. 3, 4). A flint "finger" with engraved parallel lines was found at the Geometric Kebaran site of Neve David (Kaufman 1999). Sets of short parallel incisions on bone tools were more common, e.g., Ohalo II (including an engraved wood object; Rabinovich \& Nadel 1994-5; Nadel et al. 2006: fig. 18), Ksar 'Akil (Tixier 1974), Jiita (Copeland \& Hours 1977) and Kharaneh IV (Muheisen 1988: fig. 3).

These early examples along with other Palaeolithic cases were, for a long time, at the heart of archaeological and art-history debates, mainly concerning their meaning in relation to topics such as human evolution, cognition, culture and art (e.g. Hovers 1990; Bar-Yosef 1997; Marshack 1997). Notably, the Natufian culture in the Levant, and specifically in the Mediterranean southern Levant, provides unprecedented examples of art and ornamentation in general (e.g. Garrod \& Bate 1937; Larson 1978; Belfer-Cohen 1988, 1991b; Weinstein-Evron \& Belfer-Cohen 1993; Belfer-Cohen \& Bar-Yosef 2009), and stone art objects that involved engravings and incisions in particular (Shaham \& Belfer-Cohen 2013 and references therein), all indicating innovative approaches to the use of objects in their symbolic world (BelferCohen \& Bar-Yosef 2009).

In the Natufian, patterned incisions are common and found on several types of objects and raw materials. While it is by no mean the attempt of this paper to provide an over-view of 
all cases, several are pertinent to the following discussion and are thus presented below. Three aspects are pivotal here, namely the patterns, the platform on which they were carved and their archaeological context.

The most recent work done in this regard was carried out on seven stone objects from Hayonim Cave (Shaham \& Belfer-Cohen 2013). One of these was a large stone block incorporated in a pavement within a structure. Overall, this object was perceived by the Natufian artisans as three dimensional although the depiction technique is two dimensional. The incisions are of various directions, depths and patterns, and found on three sides of the stone. There are sets of parallel lines in the same length, and isolated lines in various lengths and directions. Many look random at first glance, suggesting that the action of incision was more important than the final "product" (Shaham \& Belfer-Cohen 2013: 409, fig. 1).

Four additional slabs were analyzed, with somewhat different incised patterns. Shaham and Belfer-Cohen (2013: 415) concluded that: "thus, we may define different styles, and different modi of art creation yet they share artistic elements in terms of motifs, composition, technique and raw-material." All analyzed examples have an incised linear composition. They added: "Two basic artistic modi were identified on the Hayonim sample. One is a more organized modus of pre-planned pictorial compositions. It is defined by carefully arranged, dense and enclosed linear composition, made of clear repetitive incised lines of more regular spacing. The second is the "action" modus observed on the big stone slabs and block, whereas even if pre-planned linear compositions were incised, they are more open graphic depictions in terms of compositional structure as well as the actual technique and style (e.g., lines are varied in length, depth, orientation, etc.; sometimes the depictions are almost un-observed by the naked eye)" (Shaham \& Belfer-Cohen 2013: 416).

Stone items bearing incised and engraved patterns were found in other Natufian sites. These include Hayonim Terrace, where a small pebble was found, bearing several sets of incisions on one side, the most elaborate of which includes two parallel lines about 1-1.5 cm apart and ca. $6 \mathrm{~cm}$ long, with short lines in-between (Valla 2012: fig. 3). The latter are 1.5-3 $\mathrm{mm}$ apart, and the sets and subsets were incised by different 'points', at different angles, and with different pressures (Marshack 1997: 72). A set of short parallel lines are perpendicular to the edge of the stone where they end, and another set by the edge is diagonal to it. There are also isolated long lines incised on this item.

Engraved stone items were also reported from sites such as Eynan (e.g., Perrot 1966; Valla et al. 2004: 219, figs. 73, 74); el-Wad Cave and terrace (Weinstein-Evron 1998: 63; Rosenberg et al. 2012: fig. 19;); Wadi Hammeh 27 yielded the largest assemblage of engraved and decorated objects, as well as a set of large decorated slabs that were found incorporated in a wall (Edwards 2013: figs. 4.25, 12.3-12.5).

\section{Materials and methods}

\subsection{Raqefet Cave}

Raqefet Cave is situated in a small wadi within the Mt. Carmel range, Israel (Figure 1). The cave is ca. 50 long, opening to the west. It was first excavated by Noy \& Higgs (1971) and later for five seasons by us (e.g., Nadel et al. 2008, 2009a, 2013; Lengyel et al. 2013). Natufian remains were exposed in the first chamber and on the terrace.

The Natufian remains at the site comprise of two types of in situ features. The first is a dense graveyard, with some 30 burials, and all but one found in a restricted area by the north wall of the first chamber (Nadel et al. 2012; 2013). Most are single interments, though there are four double burials. Furthermore, there are some cases of repeated burial in the same location, a practice by which early burials were disturbed by the later reburial events. Three dates were obtain directly from human collagen of three individuals, ranging between ca. 
13,500 and 12,200 years cal BP (Nadel et al. 2013). In four graves, the impressions of a preburial lining consisting of green plants and flowers were well-preserved (Nadel et al. 2013).
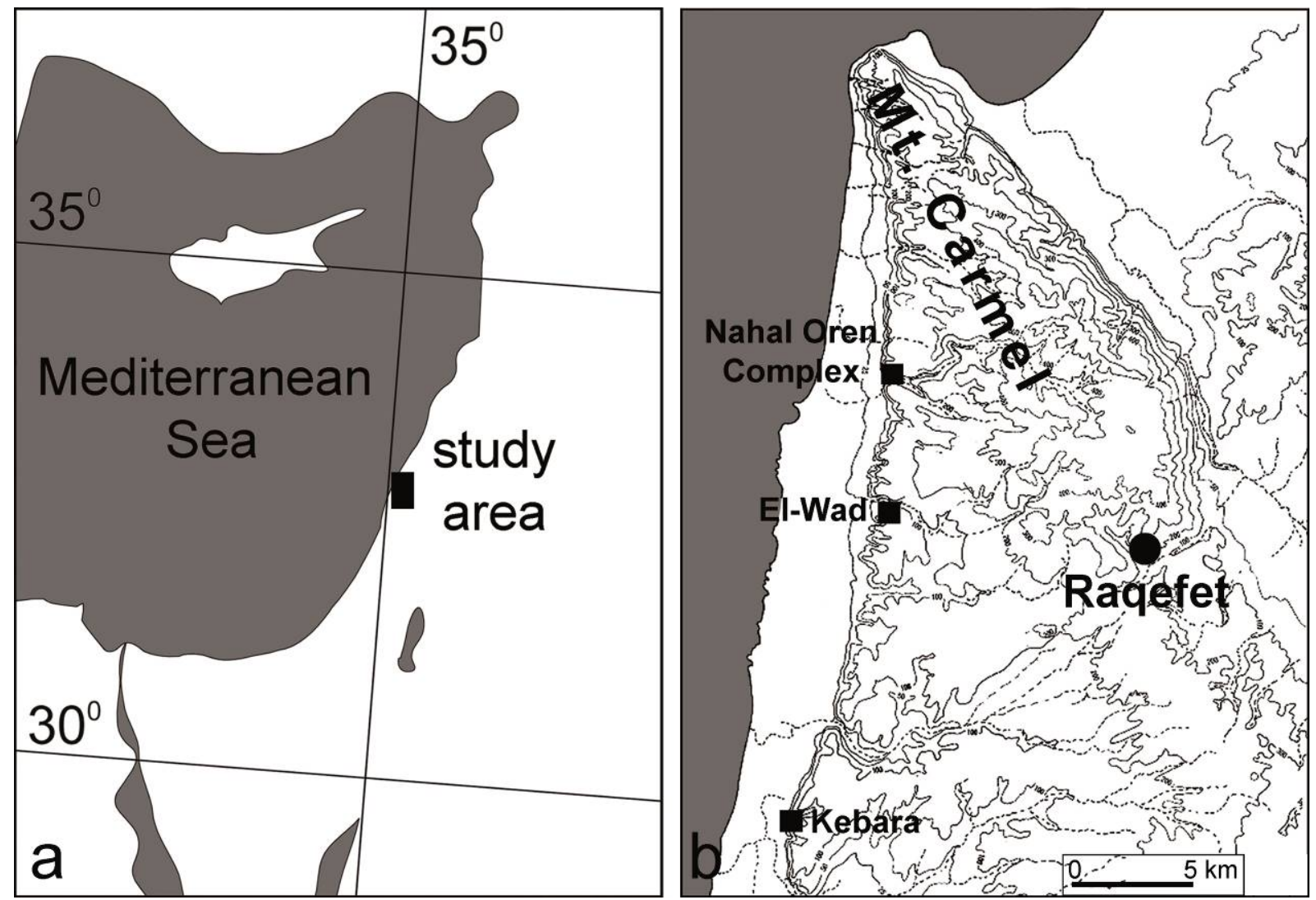

Figure 1. Location map of Natufian sites in Mt. Carmel, Israel.

The second prominent feature includes ca. 100 bedrock features. These are present in a very wide range of types (Figures $2 \& 3$ ), including tiny holes only several $\mathrm{cm}$ across and 1-3 cm deep, cupmarks, bowl-like specimens, small mortars, deep narrow mortars and large basins (e.g., Nadel \& Lengyel 2009; Nadel et al. 2009; 2012). The entire range of types was found on the floor of the first chamber. However, only small cupmarks were found in an alcove ca. $1.5 \mathrm{~m}$ above the chamber's floor, and a few were found on the top of a large rock that fell from the cave's ceiling or wall. On the terrace 30 specimens were found, with a range of small cupmarks and bowl-like specimens, but none with a deep narrow shaft. A phytolith study included the sampling of eight of the burials and four of the bedrock features (Power et al. 2014). The microscopic remains from within the mortars include phytoliths of cereals such as wild barley, wheat, small-seed grasses, and reeds.

In order to accurately document and characterize the bedrock features, we used photogrammetry and high-resolution 3D models (Miller et al. 2014; Nadel et al. 2015). The application of photogrammetry to deep bedrock features requires certain adjustments, especially as the studied object is a hollow, while in most archaeological cases it is not. In principle, close-range images from different positions and vantage points are acquired to allow for detailed mapping of the features. Point cloud extraction was performed, while the evaluation of the mortar's metrics was implemented using Matlab software (www.mathworks.com). Both point cloud extraction and metrics computation were run on a standard desktop computer. The number of images per bedrock feature discussed here was ca. 20 and sets of scale bars were used during photography to ensure proper scaling. The derived model consists of both the bedrock feature (mortar) and the adjacent bedrock surface. Density 
and spatial distribution of the point cloud were analysed via triangulation of the point-set and assessment of the average arc-length and entrapped area per triangle. Once a scaled 3D model of each feature was established, it served as the basis for a variety of measurements and analyses.

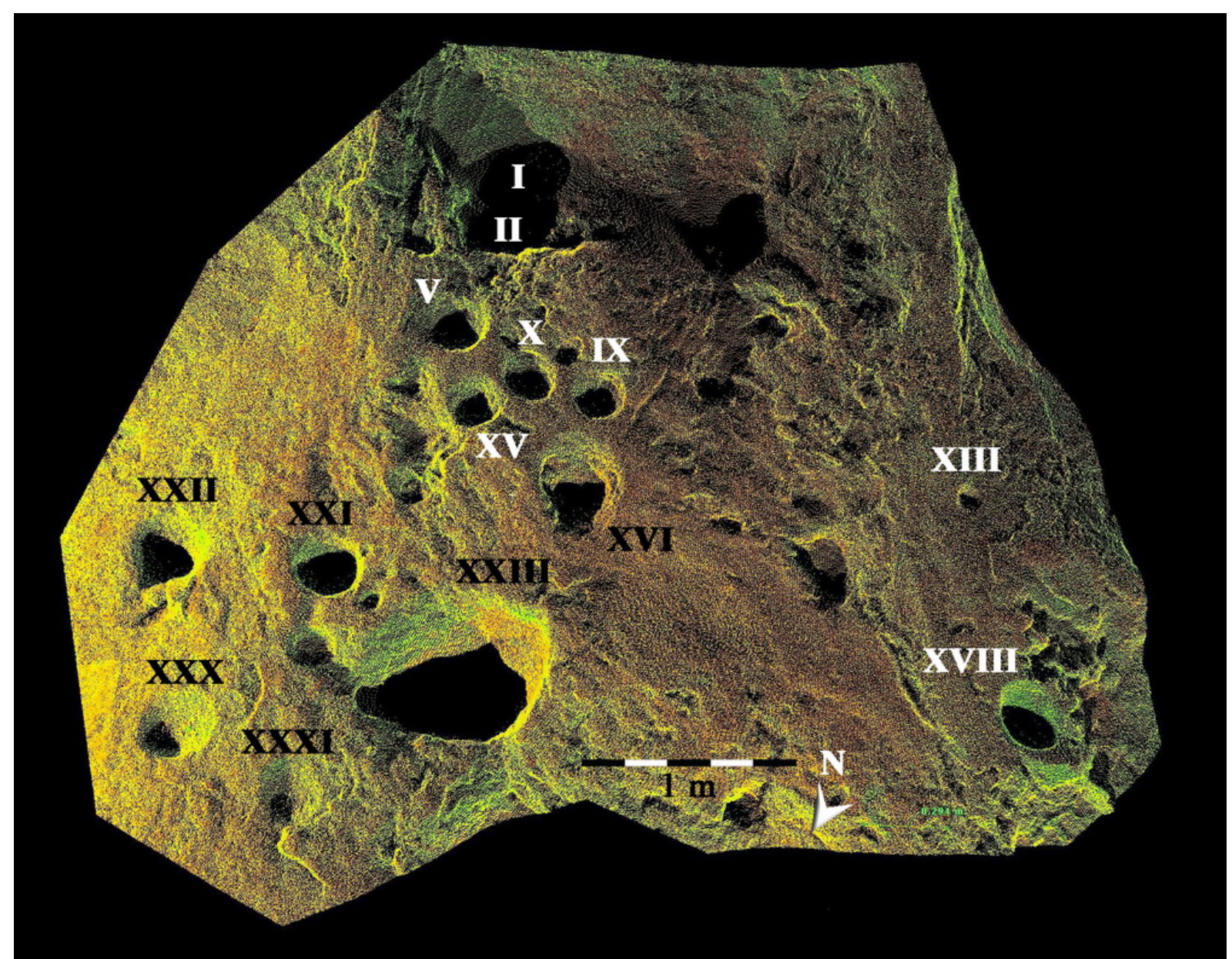

Figure 2. A panoramic view of the first chamber floor of Raqefet Cave, with location of bedrock mortars mentioned in the text (prepared from a 3D model, courtesy of S. Filin).

\subsection{Deep narrow mortars}

Among the wide variety of bedrock features at Raqefet Cave there are only three that are deep and narrow, including mortar C-XVIII which is the focus of this paper. They are all 40$60 \mathrm{~cm}$ deep, with a top diameter of 20-25 cm. However, they differ in their geometry and context.

Mortar C-XVI is the only mortar with a funnel-like morphology. Half way down, where the top wide part becomes a vertical narrow shaft, an isolated stone was found. It was set firmly, as if to serve as a 'cork' (Nadel \& Lengyel 2009). Below it, the shaft contained the typical Natufian red sediment, with small animal bones, lunates - the hallmark of the Natufian flint industry_and phytoliths of large seed grasses (Power et al. 2014). The walls of the shaft are badly eroded. The mortar was carved near several bowl-like features (Figures 2 and 3), and none of the nearest ones is deep (i.e. over $30 \mathrm{~cm}$ ).

Mortar C-XXI is the deepest of the three mortars and has a narrow vertical shaft ca. 60 $\mathrm{cm}$ deep. The walls of the shaft are preserved only in several small patches. It is located near the largest man-made bedrock basin ever reported from a Natufian site (C-XXIII, Figures 2 
and 3). Furthermore, there are several small cupules or holes near this mortar, and one even carved on its rim. Mortar C-XVIII is described separately below.

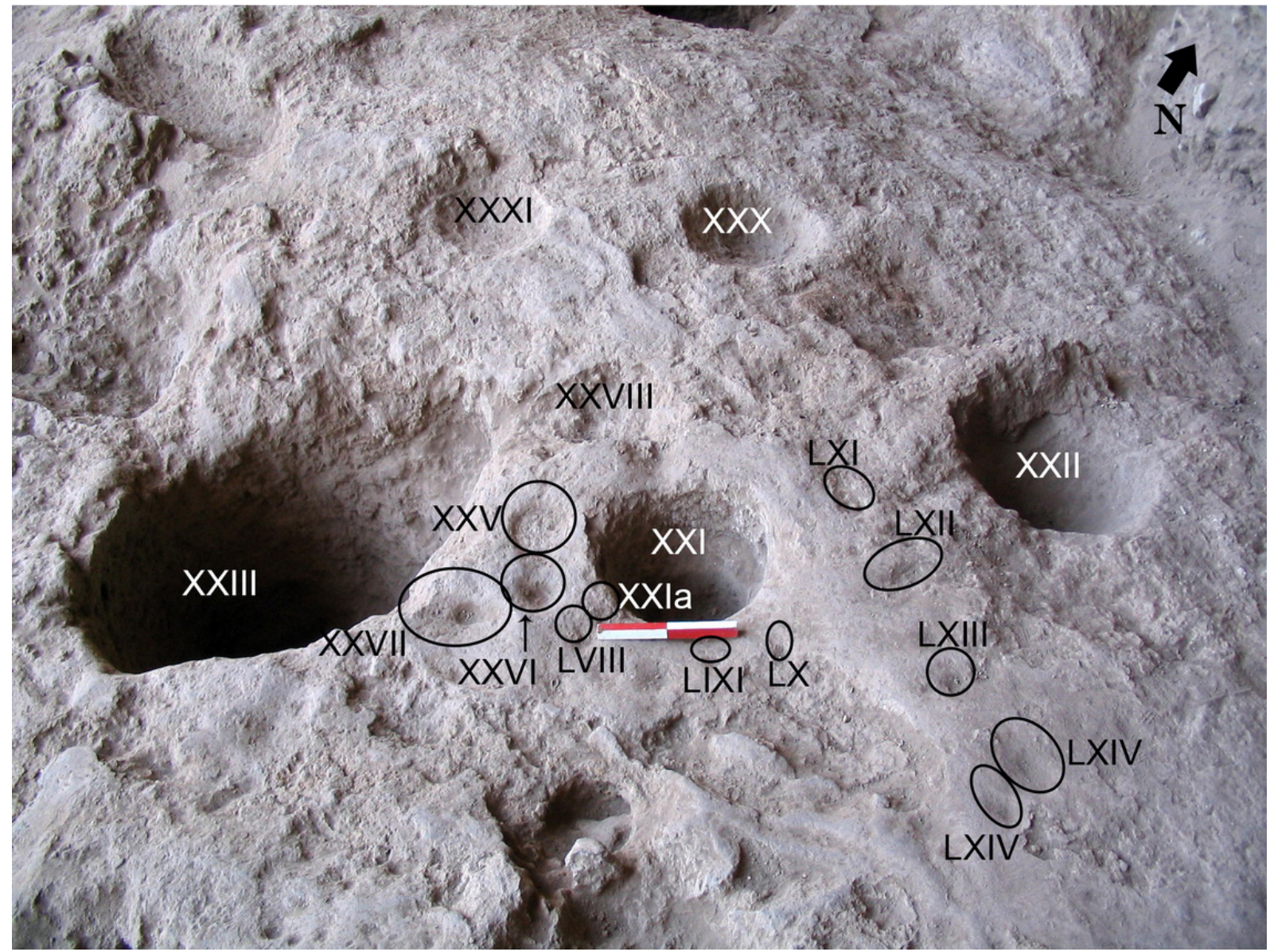

Figure 3. The highest concentration of bedrock features on the floor of chamber 1, Raqefet Cave. The largest Natufian bedrock basin (C-XXIII) is located here; the deep narrow mortar C-XXI is in the center, with a variety of features around it. Mortar C-XVIII is to the left, beyond the photo. Scale $20 \mathrm{~cm}$.

Noteworthy, deep narrow mortars are rare in other Mt. Carmel Natufian sites. For example, at the large el-Wad site no similar mortars have been documented (Garrod \& Bate 1937; Weinstein-Evron 2009; Weinstein-Evron et al. 2013: fig. 4). At Nahal Oren there are only three known bedrock mortars, and they are not nearly as deep as the ones discussed here (personal observation).

However, one such mortar was found on the terrace of a small cave (site 22) ca. $100 \mathrm{~m}$ from the Nahal Oren site. It was in a detached rock tilted sideways with a 50-cm deep shaft (Nadel et al. 2011: fig.13; Nadel et al. 2012: fig.20). One mortar in that cave (site 22) had a 'cork' stone in its vertical shaft, about $20 \mathrm{~cm}$ below the rim. The stone was not extracted but it seems that this mortar is also very deep (Nadel et al. 2011: fig.13; Nadel et al. 2012: fig.17). Such mortars have not been reported from other Natufian sites located in the Mediterranean zone of the southern Levant, such as Hayonim Cave and Terrace (Belfer-Cohen 1988), Hilazon Tachtit (Grosman et al. 2008) and Eynan (Perrot 1966; Perrot \& Ladiray 1988). However, similar items are known from Huzuk Musa in the lower Jordan Valley (e.g., Eitam 2008; 2010; Rosenberg et al. 2010; Nadel \& Rosenberg 2013) and Rosh Zin in the Negev (Nadel et al. 2009b). 


\subsection{Mortar XVIII}

Mortar C-XVIII is located on the western edge of the floor of the first chamber in Raqefet Cave, just above a large depression in the bedrock (Locus 2), which is almost $1 \mathrm{~m}$ deep (Nadel et al. 2008) (Figures 2 \& 4). In contrast to the other two deep mortars, there are no adjacent bedrock features, and the nearest specimen (ca. $0.8 \mathrm{~m}$ away) is a small mortar with its rim eroded by exfoliation. The adjacent depression termed Locus 2, ca. $3 \mathrm{~m}$ across, was filled with sediment and at the top part, near the cave floor's edge, there were two noteworthy phenomena. The first was a disturbed pavement of slabs set horizontally at the edge of the floor and at the same height. The second was a boulder mortar, found in situ with its rim just $15 \mathrm{~cm}$ above the level of the floor and pavement, only $30 \mathrm{~cm}$ from the rim of CXVIII (Figures $5 \&$ 6). It thus appears that C-XVIII was carved at the edge of the floor and a pavement and a boulder mortar were set adjacent to the mortar.

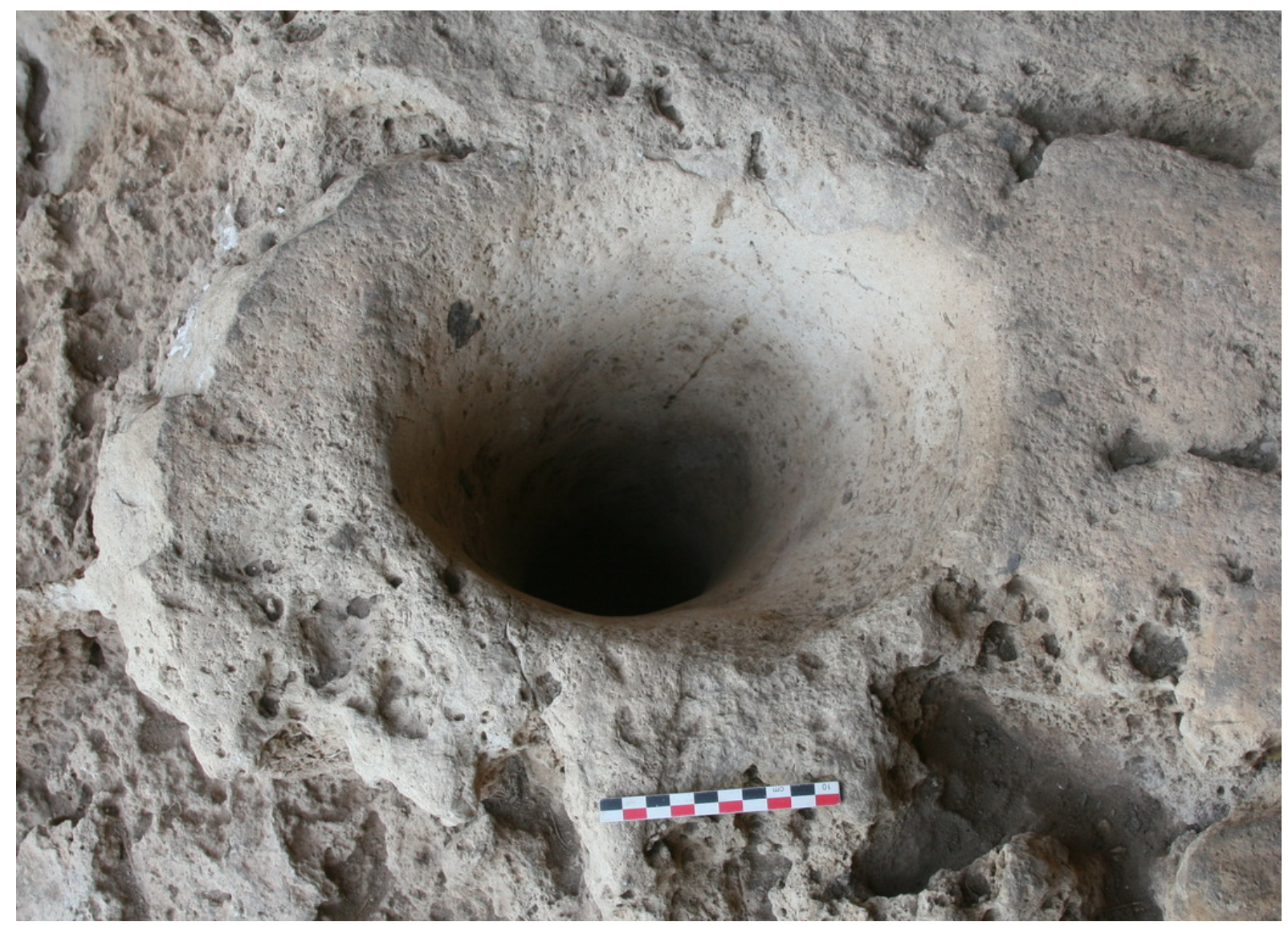

Figure 4. Top view of Mortar C-XVIII.

The location and setting of a deep narrow bedrock mortar near a pavement and a boulder mortar are unique at the site. The combination of pavements and boulder mortars, and sometimes also bedrock features, were noted in other sites such as Eynan (Perrot 1966; Perrot \& Ladiray 1988: fig. 9), el-Wad (Garrod \& Bate 1937; Weinstein-Evron 2009; fig. 3.11b), Nahal Oren (Stekelis \& Yizraely 1963; Noy 1989), Rosh Zin (Henry 1976) and Shubayqa 1 (Richter et al. 2012: fig. 7).

The C-XVIII mortar is $53 \mathrm{~cm}$ deep; it is $25 \mathrm{~cm}$ wide at the rim and ca. $8 \mathrm{~cm}$ wide near its base (Figure 7). The area near the opening is smooth (Figure 4) and large sections of the shaft wall are very well-preserved. However, several cracks are visible inside, as is the case for most large bedrock features at the site. The mortar was found full of grey sediment, likely a mixture of Natufian and later contamination. 

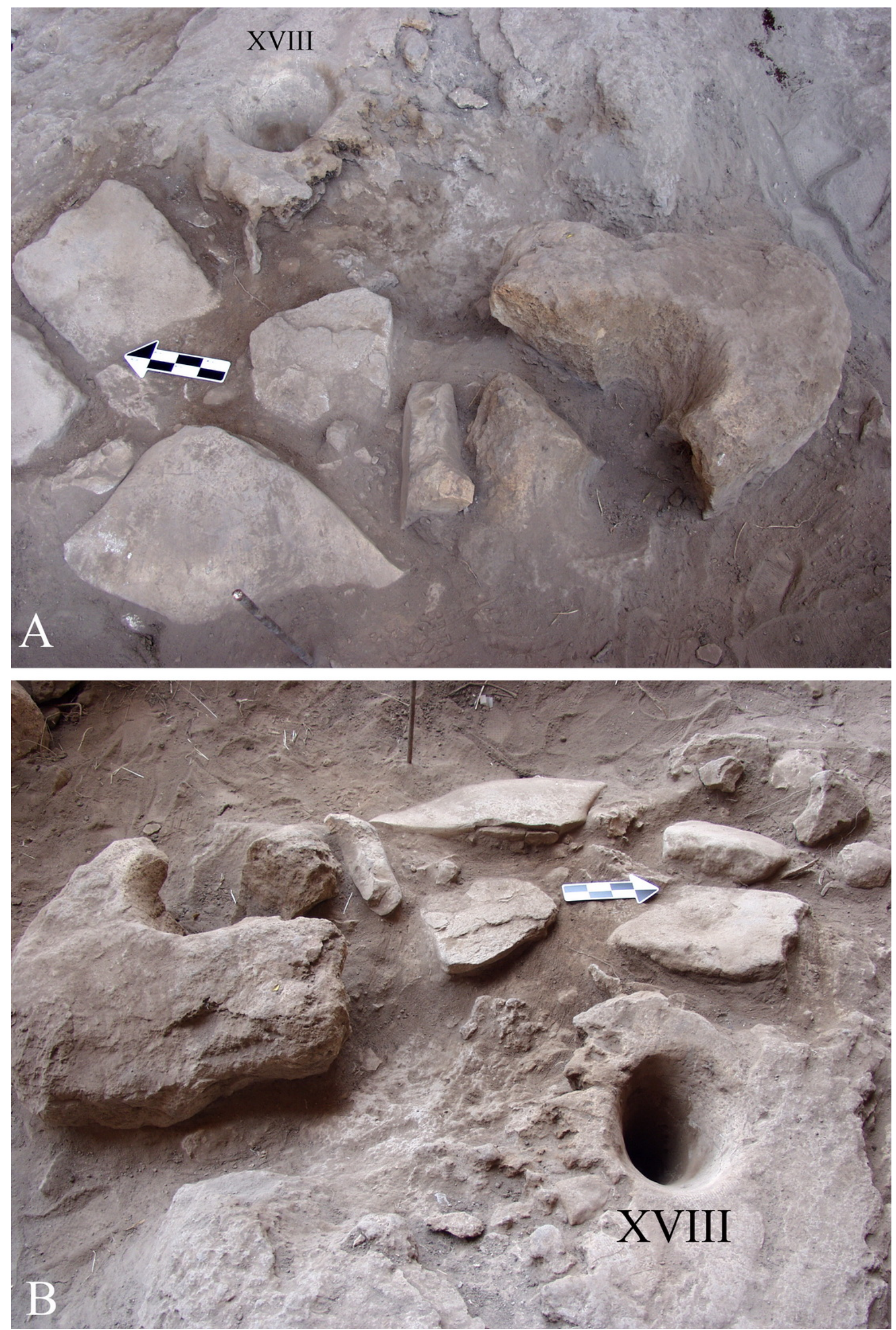

Figure 5. Two views of mortar C-XVIII, the split boulder mortar and the stone pavement - all with their tops at roughly the same level. Scale arrow $20 \mathrm{~cm}$. 


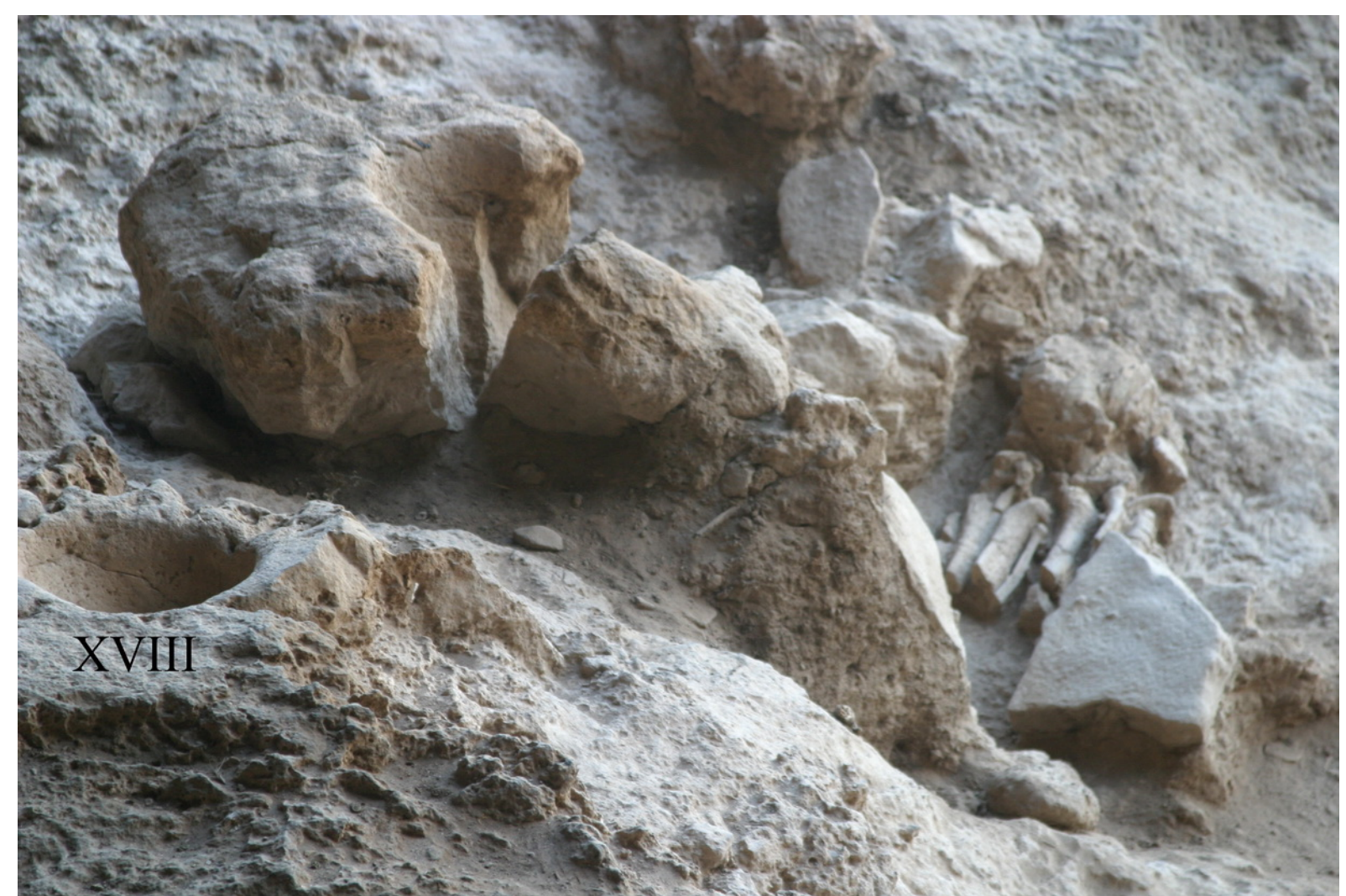

Figure 6. Mortar C-XVIII with the split boulder mortar behind it, and a Natufian skeleton below.

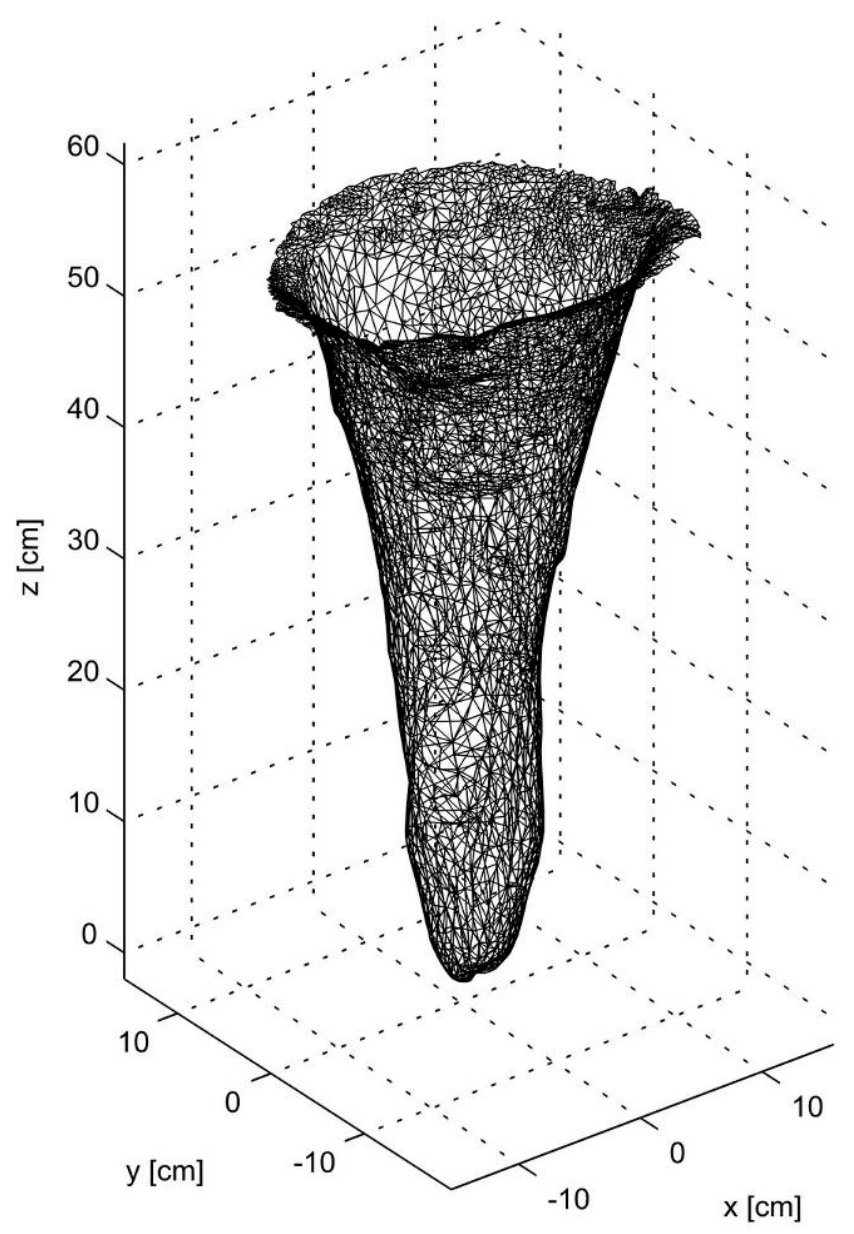

Figure 7. A photogrammetric, 3D mesh of Mortar C-XVIII. 


\subsection{The incisions}

The incisions discussed hereby are found inside the shaft, just below the rim. They cover an area of ca. $10 \times 15 \mathrm{~cm}$ (Figures 8 and 9). A curved horizontal crack crosses the incised area, and there are several natural post-incision holes in this area with more damage around the edges of the smooth area.

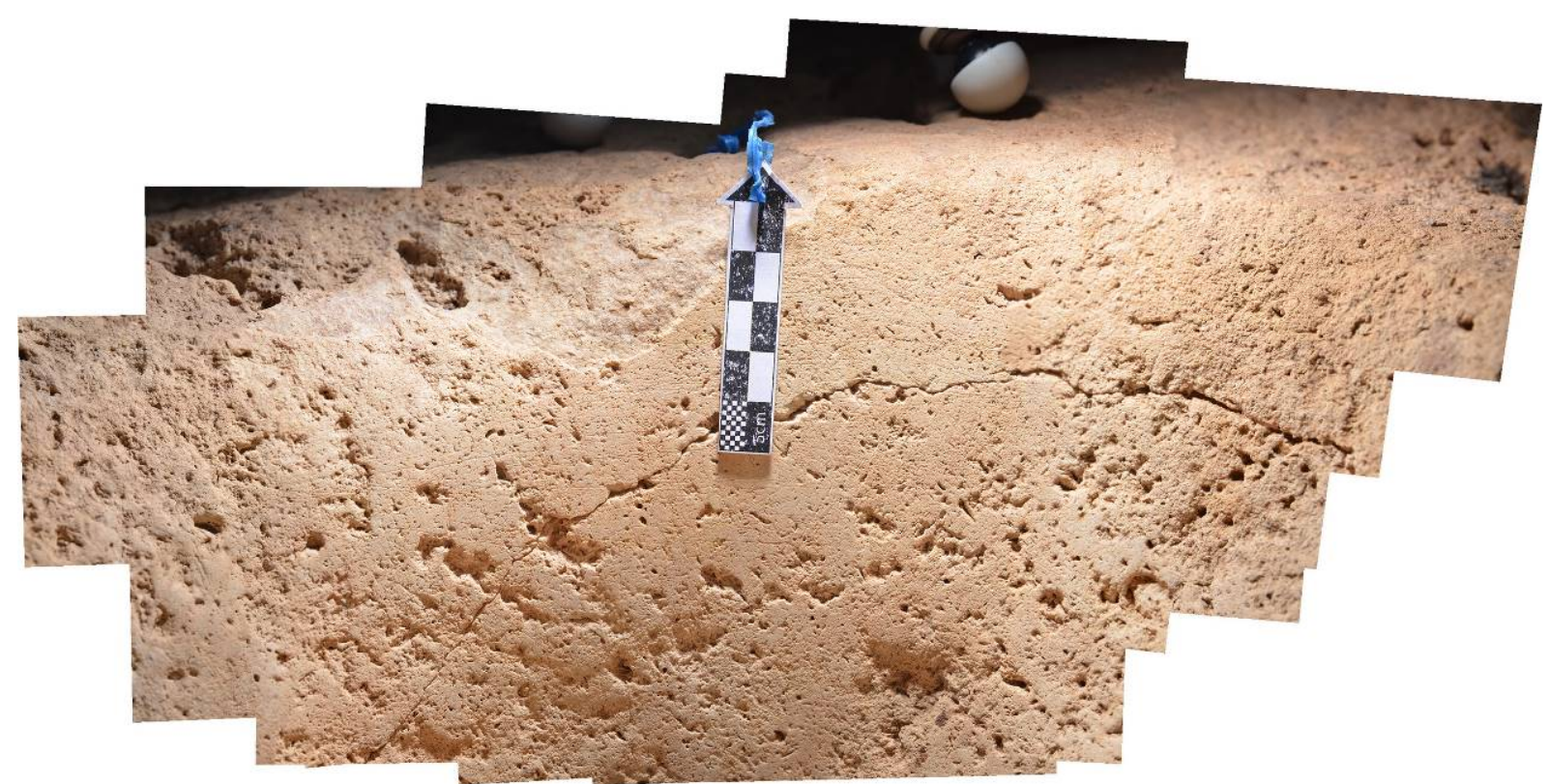

Figure 8. A panoramic view of the top of the shaft, mortar C-XVIII. The smooth area above and below the horizontal crack is the richest in terms of preserved patterned incisions (Scale is $5 \mathrm{~cm}$, photograph by E. Crater Gershtein).

About 200 incised lines were traced, although a number of faint marks that were not traced are also visible. The incisions are delicate, mostly ca. $0.2-0.4 \mathrm{~mm}$ wide and $0.1-0.2$ mm deep (Figures 10 to 12) and were likely produced by a sharp flint item.

At the bottom part of the panel almost all incisions are vertical and are generally 2-4 cm long (Figure 9). The central and top parts of the panel are covered by a dense concentration of horizontal and vertical lines, with a few diagonal lines. When high-resolution images are inspected, it becomes clear that a grid-like pattern is prevalent in the center (Figures $10 \& 11$ ) with horizontal and vertical incisions. These lines are spaced at intervals of 6-7 $\mathrm{mm}$. The dimensions of the grid squares are similar, with $90^{\circ}$ angles between the lines. Some lines were enhanced several times, less than $1 \mathrm{~mm}$ apart and likely, this was aimed to ensure that the lines are large enough to be visible; this was done for vertical, horizontal and diagonal lines (Figure 12: 1). Where possible to discern, the vertical lines are later than the horizontal ones (Figure 12: 1, 2). In other words, it appears that the grid was executed by first marking the horizontal lines, and then adding the vertical ones.

The isolated diagonal lines are among the longest preserved incisions (Figure 9). These appear to be among the last incised, as they cross many horizontal and vertical lines (Figure 13: 1). In addition, there are sets of very dense parallel lines, usually lighter than the abovedescribed incisions. These are hardly visible on the general scale (Figure 9) and discernible only under magnification (Figure 13: 2). Such short dense sets may reflect use-wear of a rough stone working on the surface of the shaft, as it is hard to conceive a repetitious engraving work where the distance between many delicate lines are $1 \mathrm{~mm}$ or less.

In a general inspection of the panel, several additional patterns are discernible (Figure 9). First, as stated above, the top and bottom are very different; the former has a grid-like pattern with many horizontal and diagonal lines, some of which are the longest present; the latter is 
solely composed of short vertical lines. The grid-like pattern is regular, and several sections of it have been preserved, while in-between erosion or later incisions obliterate the pattern. There are several sets of short clustered parallel lines, both in horizontal and vertical orientations. The larger sets are of deliberate incisions, the smaller may be use-wear signs.

On the eastern side of the studied incised area, where the grid pattern is less apparent, there are many diagonal incisions on a surface not as smooth as that carrying the grid (Figures 9, top right \& 14).
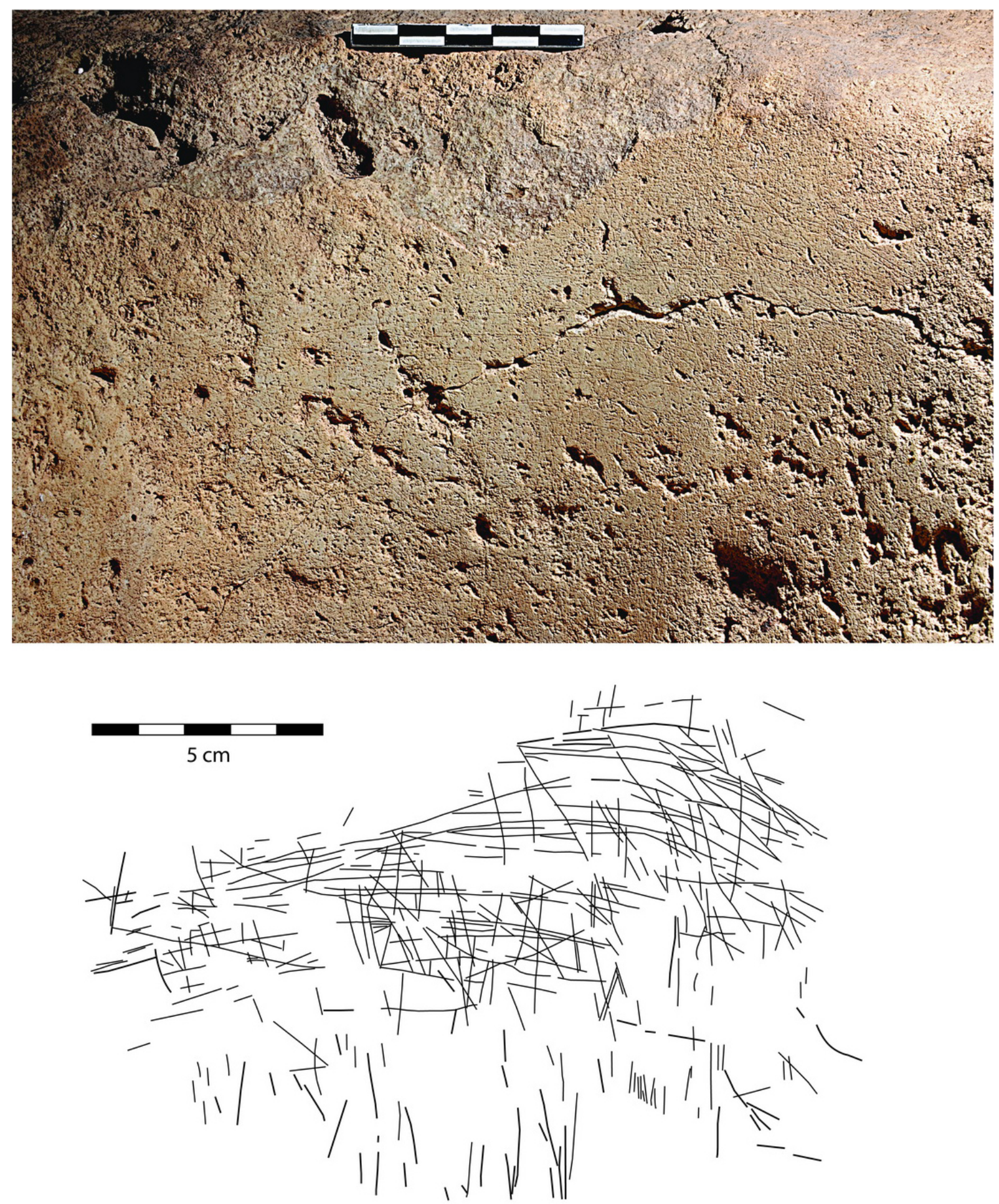

Figure 9. The incised area in photo (top) and tracings (bottom) (photograph by E. Crater Gershtein). 


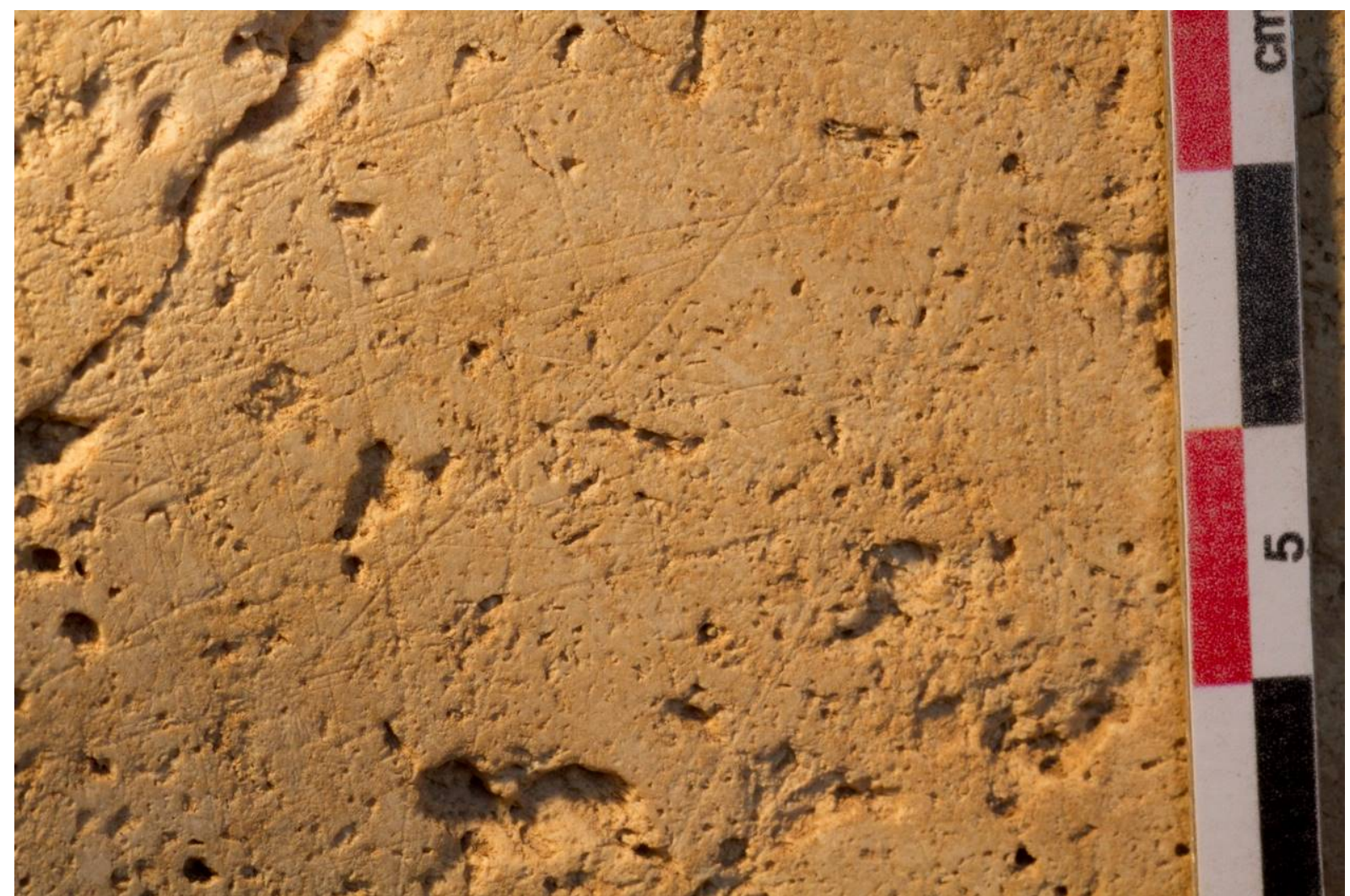

Figure 10. A view of a preserved section with incisions (scale in $\mathrm{cm}$, photograph by E. Bartov).

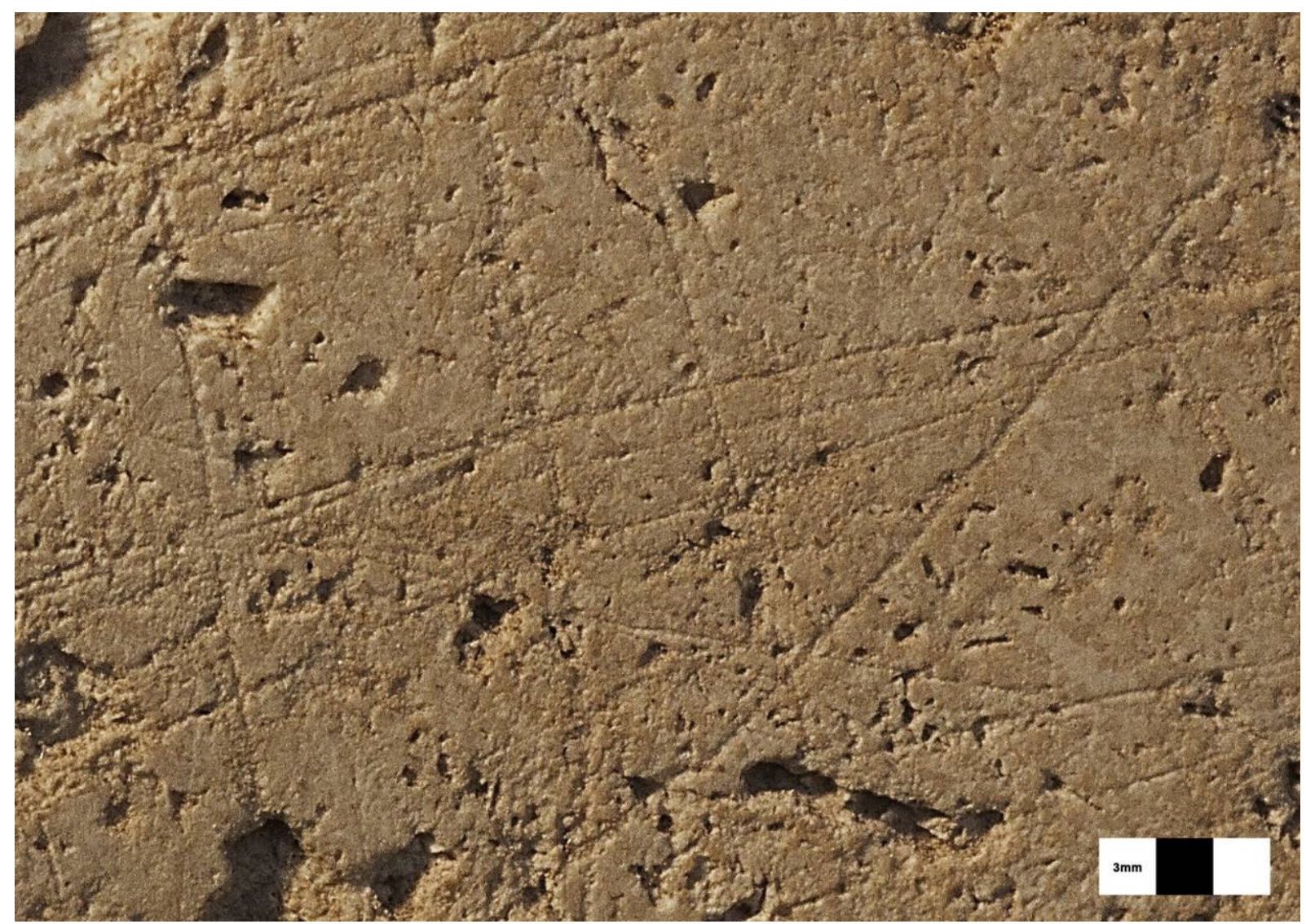

Figure 11. An enlargement of the grid-like pattern (photograph by E. Crater Gershtein). 


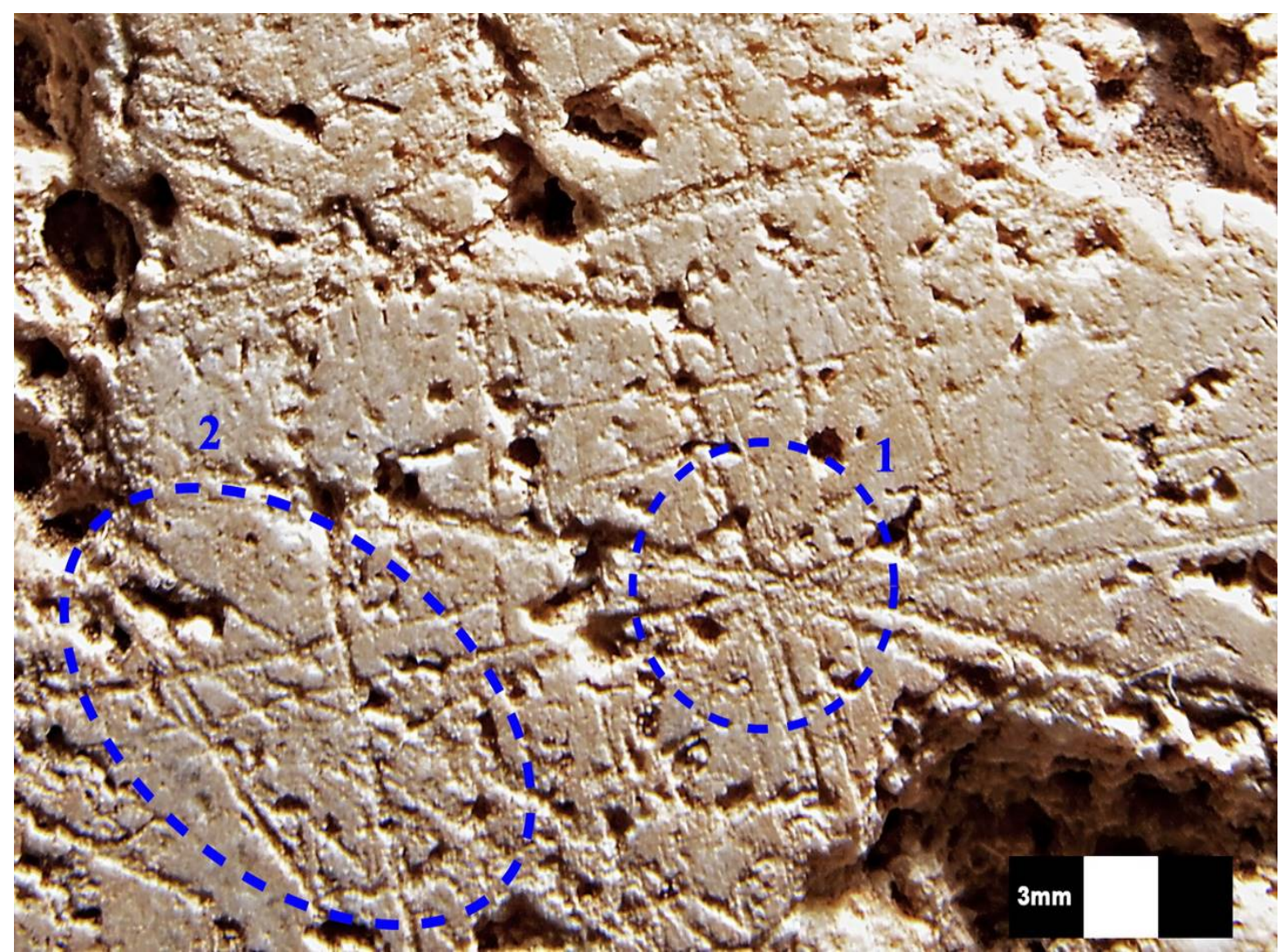

Figure 12. A view of a preserved section with incisions. Note the double lines within the marked areas $(1,2)$, as well as the vertical lines crossing the horizontal ones in both marked locations (photograph by E. Crater Gershtein).

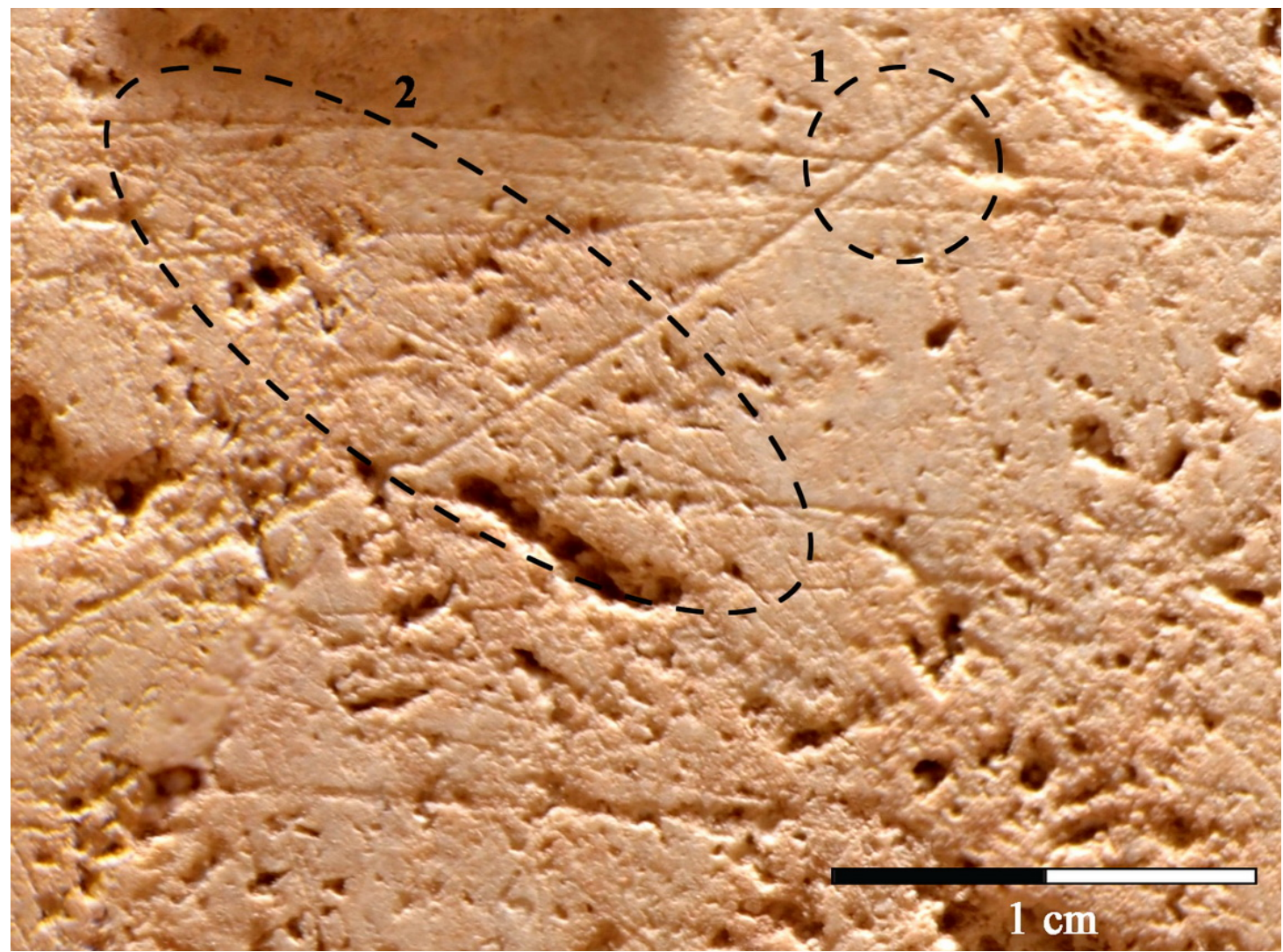

Figure 13. A view of a preserved section with incisions. Note the diagonal line crossing earlier lines (1), and the cluster of light diagonal lines (2), (photograph by E. Crater Gershtein). 


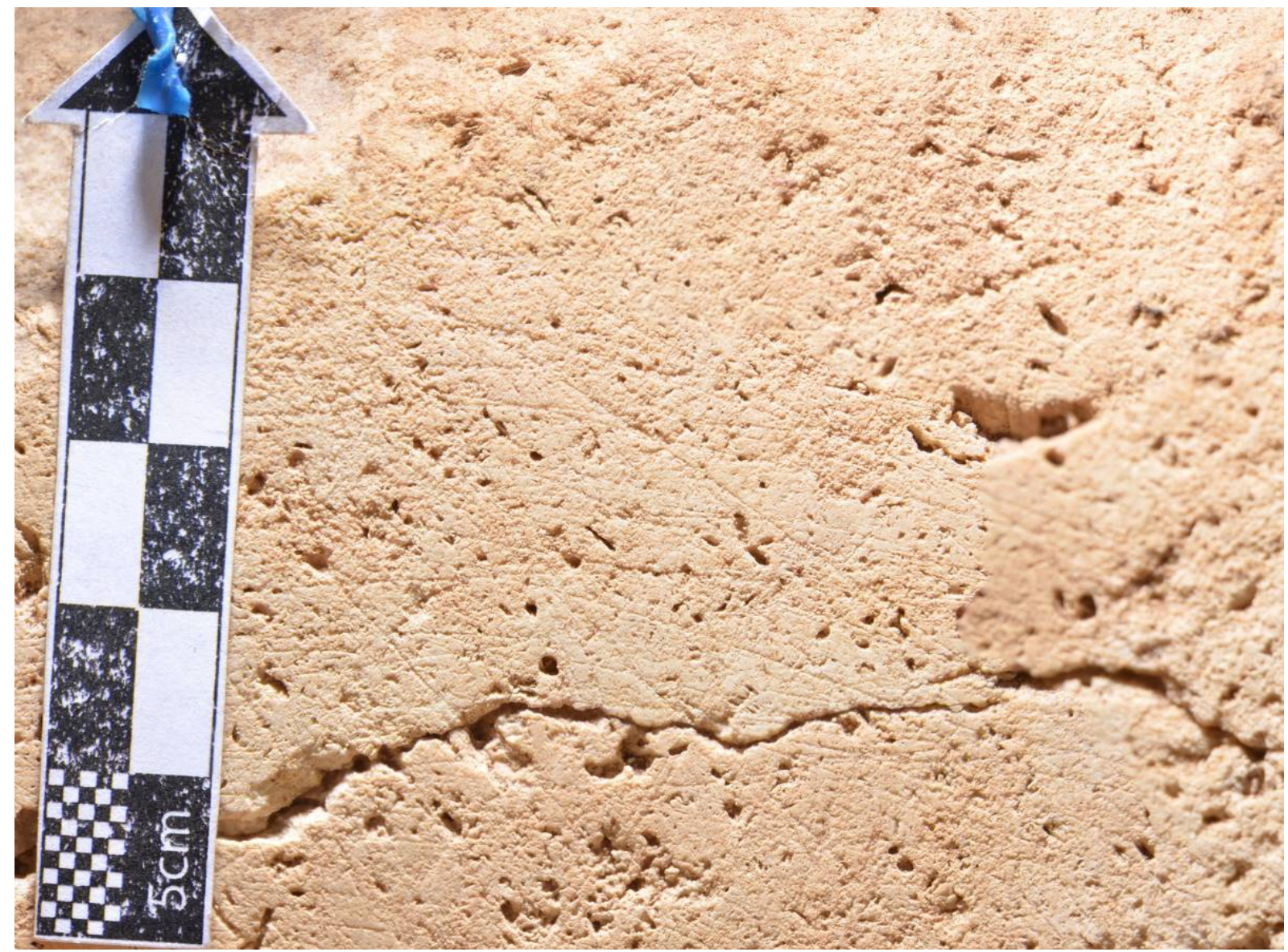

Figure 14. The top eastern edge of the incised area, with diagonal marks (photograph by E. Crater Gershtein).

It is likely that some of the light dense parallel striations are in fact use-wear marks, the results of the repeated pounding strokes in the mortar shaft. However, the grid-like pattern we described here, as well as other incisions, cannot be explained either as use-wear or production marks. It is also clear that the incised patterns documented in mortar C-XVIII were hardly affected or obliterated by food or mineral processing in the deep shaft. In turn, this suggests that either the work in the mortar ceased (the mortar went out of use) after the shaft was adorned or supplemented with the incised designs, or that the work continued but with pestles made of soft material (possibly wood) or in a light manner not affecting the top of the shaft where the incisions are located.

\section{Discussion}

Natufian stone objects bearing incised patterns include stone tools (e.g., pestles, mortars, bedrock features) as well as various slabs and pebbles. The examples describe from Hayonim Cave (Shaham \& Belfer Cohen 2013) and other sites (section 2, above) reflect the fact that regardless of the stone platforms they were engraved on, Natufian incised motifs are of various styles and patterns, some of which are not found on all objects. Some items bear incisions that have discernible "figurative" patterns while others do not.

In most Natufian cases, including Mortar C-XVIII, the incisions are usually very shallow and narrow, and thus hardly visible. Elaborate sets often include a crisscross or ladder-like pattern, a grid or clusters of parallel lines. Interestingly, there are striking similarities between different objects and different sites in terms of size (length, depth, width) and spacing of lines in the regular patterns. The more loose and irregular incisions appear in various directions and 
lengths, and, apparently, these were usually carved later than the more elaborate designs, perhaps to obliterate or erase the earlier incisions.

It is common to find three types of incisions on the same object (both on the stone objects from Hayonim Cave (Shaham \& Belfer Cohen 2013) and mortar C-XVIII): a) patterned sets, within a delineated space (e.g., ladder-like, grid); b) small sets of dense parallel incisions, usually shorter and lighter than the patterned sets, and not on the same axis or in the same orientation; c) isolated incisions, in various directions and lengths.

The stone platforms on which the Natufians chose to place the engravings are varied. Large slabs were used as platforms which bear large elaborate motifs (Edwards 2013: figs. 12.3, 12.4). At the same time, the Natufians also modelled, carved or marked other objects; some are shaped tools like vessels and pestles, and some are 'plain' objects like pebbles and slabs (e.g., Perrot 1966; Noy 1991: figs. 2, 3; Weinstein-Evron 1998: 63; Rosenberg et al. 2012: fig. 19; Edwards 2013; Shaham \& Belfer-Cohen 2013).

Thus, not all objects received the same 'treatment' and in some the motifs are shaped in relief, and are much more 'invested', while in others it seems that the incised pattern was deliberately made not to 'stand out'. This could be a functional derivative, if the incised patterns are related to a specific magical apparatus or a result of a more casual manner in which they were designed. As pointed out by Shaham \& Belfer-Cohen (2013), the impression is that the incision makers were not concerned with visibility, it was the process and symbolic meaning that were the dominant factors in the execution of the desired patterns and lines. The very act and knowledge of the act were important, not the visibility of the outcome. It should also be noted that regarding the C-XVIII mortar case, it seems that no substantial pounding or crushing was carried out in the mortar after the incisions were performed. Thus, it remained part of a structured complex with two components: the visible one, encompassing a pavement, a boulder mortar and a bedrock mortar, and an invisible one, encompassing an almost-hidden set of delicate symbols, and possible other unpreserved components.

In terms of the archaeological context, it seems that items bearing incised patterns are mostly found on objects set away from daily visibility, in the cases of the slabs from Hayonim Cave and the mortar from Raqefet Cave. In a more general way, such items and even the more elaborate engraved objects are found both in hamlets and in burial caves.

In conclusion, the incised patterns documented in the deep C-XVIII mortar at the entrance to Raqefet Cave is now added to the large array of Natufian engraved specimens and 'art objects'. The complex motif, the specific feature it was carved on (inside a deep mortar), the setting within a structured complex and the location at the entrance to a burial cave all suggest an elaborate symbolic system in which it may have operated. The mortar and its concealed incised pattern are yet another aspect of the complex symbolic and spiritual worlds of the Natufians, not always fully understood but with a wide range of relevant material remains, as expressed in Natufian burial customs and art manifestations.

\section{Acknowledgements}

We thank A. Regev-Gisis here for help with constructing the digital illustrations.

\section{References}

Bar-Yosef, O. 1981, The Epipalaeolithic complexes in the Southern Levant. In: Préhistoire du Levant. Chronologie et Organisation de L'espace Depuis les Origines Jusqu'au VIe Millénaire, (Cauvin, J., \& Sanlaville, P., Eds.), Colloques Internationaux du C.N.R.S. 598, Edition Centre National de la Recherche Scientifique (CNRS), Paris: p. 389-408. 
Bar-Yosef, O. 1983, The Natufian in the Southern Levant. In: The Hilly flanks and beyond: Essays on the Prehistory of Southern Asia Presented to Robert J. Braidwood (CuylerYoung, T. Jr., Edwards, P., Smith, L., \& Mortensen, P., Eds.), Studies in Ancient Oriental Civilization 36, Oriental Institute, University of Chicago, Chicago: p. 11-42.

Bar-Yosef, O. 1997, Symbolic expressions in later prehistory of the Levant: why are they so few? In: Beyond Art: Pleistocene Image and Symbol, (Conkey, M., Soffer, O., Stratmann, D., \& Jablonski N.G., Eds.), Memories of the California Academy of Sciences Vol. 23, University of California Press, San Francisco: p. 161-187.

Bar-Yosef, O. 2002, Natufian: A complex society of foragers. In: Beyond Foraging and Collecting: Evolutionary Change in Hunter-Gatherer Settlement Systems (Fitzhugh, B., \& Habu, J., Eds.), Kluwer Academic/Plenum, New York: p. 91-149.

Bar-Yosef, O., \& Belfer-Cohen, A. 1989, The origins of sedentism and farming Communities in the Levant. Journal of World Prehistory, 3(4): 447-498. doi:10.1007/BF00975111

Bar-Yosef, O., \& Belfer-Cohen, A. 1999, Encoding information: unique Natufian objects from Hayonim Cave, Western Galilee, Israel. Antiquity, 73: 402-410. doi:10.1017/S0003598X00088347

Bar-Yosef, O., \& Belfer-Cohen, A. 2002, Facing environmental crisis. Social and cultural changes at the transition from the Younger Dryas to the Holocene in the Levant. In: The dawn of Farming in the Near East (Rene, R., Cappers, T.J., \& Bottema, S., Eds.), Studies in Early Near Eastern Production, Subsistence, and Environment Vol. 6. ExOriente, Berlin: p. 55-66.

Belfer-Cohen, A. 1988, The Natufian graveyard in Hayonim Cave. Paléorient, 14(2): 297308. doi:10.3406/paleo.1988.4476

Belfer-Cohen, A. 1991a, The Natufian in the Levant. Annual Review of Anthropology, 20: 167-186. doi:10.1146/annurev.an.20.100191.001123

Belfer-Cohen, A. 1991b, Art items from Layer B, Hayonim Cave: A case study of art in a Natufian context. In: The Natufian Culture in the Levant (Bar-Yosef, O., \& Valla, F.R. Eds.), Archaeological Series Vol. 1. International Monographs in Prehistory, Ann Arbor: p. 569-588.

Belfer-Cohen, A., \& Bar-Yosef, O. 2000, Early sedentism in the Near East: A bumpy road to village life. In: Life in Neolithic Farming Communities: Social Organization, Identity and Differentiation, (Kuijt, I., Ed.), Plenum Publishers, New York:p. 19-37.

Belfer-Cohen, A., \& Bar-Yosef, O. 2009, First things first: abstract and figurative artistic expressions in the Levant. In: An Enquiring Mind: Studies in Honor of Alexander Marshack, (Bahn, P.G., Ed.), Oxbow Books, Oxford: p. 25-37.

Bocquentin, F. 2003, Pratiques funéraires, paramètres biologiques et identités culturelles au Natoufien: une analyse archéo-anthropologique. Doctoral Thesis in Biologic Anthropology, University of Bordeaux, Bordeaux, 631p. (in French) ("Funeral practices, biologic parameters and cultural identities during the Natufian: an archaeoanthropologic analysis”).

Boyd, B. 2006, On "sedentism” in the Later Epipaleolithic (Natufian) Levant. World Archaeology, 38(2): 164-178. doi:10.1080/00438240600688398 
Byrd, B.F. 1989, The Natufian: Settlement variability and economic adaptations in the Levant at the end of the Pleistocene. Journal of World Prehistory, 3: 159-198. doi:10.1007/BF00975760

Byrd, B.F., \& Monahan, C.M. 1995, Death, mortuary ritual, and Natufian social structure. Journal of Anthropological Archaeology, 14: 251-287. doi:10.1006/jaar.1995.1014

Copeland, L., \& Hours, F. 1977, Engraved and plain bone tools from Jiita (Lebanon) and their early Kebaran context. Proceedings of the Prehistoric Society, 43: 295-301. doi:10.1017/S0079497X00010422

Edwards, P.C. 2013, Visual representations in stone and bone. In: Wadi Hammeh 27, an Early Natufian Settlement at Pella in Jordan, (Edwards, P.C., Ed.), Culture and History of the Ancient Near East 39. Brill, Leiden and Boston: p. 287-320.

Eitam, D. 2008, Plant food in the Late Natufian: the oblong conical mortar as a case study. Journal of the Israel Prehistoric Society, 38: 133-151.

URL: http://www.jstor.org/stable/23386442

Eitam, D. 2010, Late Epipalaeolithic rock-cut installations and groundstone tools in the southern Levant. Paléorient, 35(1): 77-104. doi:10.3406/paleo.2009.5279

Garrod, D.A.E. 1957, The Natufian culture: the life and economy of a Mesolithic people in the Near East. Proceedings of the British Academy, 43: 211-247. doi:10.1017/S0003598X00029008

Garrod, D.A.E., \& Bate, D.M.A. 1937, The Stone Age of Mount Carmel. Clarendon Press, Oxford. p. 240.

Grosman, L., Munro, N.D., \& Belfer-Cohen, A. 2008, A 12,000-year-old shaman burial from the southern Levant (Israel). Proceedings of the National Academy of Sciences, 105: 17665-17669. doi:10.1073/pnas.0806030105

Hayden, B. 2004, Socio-political organization in the Natufian: A View from the northwest. In: The Last Hunter-Gatherers in the Near East, (Delage, C., Ed.), BAR International Series Vol. 1320. Archaeopress, Oxford: p. 263-308.

Henry, D.O. 1976, Rosh Zin: A Natufian settlement near Avdat. In: Prehistory and Palaeoenvironments in the Central Negev, Israel, (Marks, A.E., Ed.), SMU Press, Dallas: p. 317-347.

Henry, D.O. 1989, From Foraging to Agriculture: The Levant at the End of the Ice Age, The University of Pennsylvania Press, Philadelphia, 288 p.

Henry D.O. 1995. Prehistoric Cultural Ecology and Evolution: Insights from Southern Jordan, Plenum Press, New York, 466 p.

Hovers, E. 1990, Art in the Levantine Epi-Palaeolithic: an engraved pebble from a Kebaran site in the Lower Jordan Valley. Current Anthropology, 31(3): 317-322. URL: http://www.jstor.org/stable/2743634

Kaufman, D. 1999, A unique engraved object from the Epipalaeolithic of Israel. Rock Art Research, 15(1): 109-112.

Larson, P. 1978, Ornamental beads from the Late Natufian of southern Israel. Journal of Field Archaeology, 5(1): 120-121. doi:10.1179/009346978791489934 
Lengyel, Gy., Bocquentin, F., \& Nadel, D. 2013, Raqefet Cave (2004 - 2008 seasons of excavation). In: Natufian Foragers in the Levant: Terminal Pleistocene Social Changes in Western Asia. Proceedings of the 2nd Natufian Conference, Paris, (Bar-Yosef, O., \& Valla, F.R., Eds.), International Monographs in Prehistory, Archaeological Series Vol. 19, Ann Arbor: p. 478-504.

Marshack, A. 1997, Palaeolithic image making and symboling in Europe and the Middle East: a comparative review. In: Beyond Art: Pleistocene Image and Symbol, (Conkey, M., Soffer, O., Sttatmann, D., \& Jablonski, N.G., Eds.), Memoires of the California Academy of Sciences 23. University of California Press, Berkeley and San Francisco: p. 53-91.

Miller, V., Filin, S., Rosenberg, D., \& Nadel, D. 2014, 3D Characterization of bedrock features: A Natufian case study. Near Eastern Archaeology, 77(3): 214-218. doi:10.5615/neareastarch.77.3.0214

Muheisen, M. 1988, Le gisement de Kharaneh IV, note sommaire sur la phase D. Paléorient, 14(2): 265-269. (In French) (“Kharaneh IV deposit, brief note on phase D”). doi:10.3406/paleo.1988.4473

Murail, P., Sellier, P., \& Bocquentin, F. 2001, La population natoufienne de Mallaha (Eynan, Israël): dénombrement, âge au décès et recrutement funéraire. Paléorient, 27(1): 89106. (In French) ("The Natoufian population of Mallaha (Eynan, Israel): count, death age and recruitment funeral”). doi:10.3406/paleo.2001.4722

Nadel, D., Danin, A., Power, R.C., Rosen, A.M., Bocquentin, F., Tsatskin, A., Rosenberg, D., Yeshurun, R., Weissbrod, L., Rebollo, N., Barzilai, O., \& Boaretto, E. 2013, Earliest flower grave-lining from 13,700-year-old Natufian burials at Raqefet Cave, Mt. Carmel, Israel. Proceedings of the National Academy of Sciences, 110(29): 11774-11778. doi:10.1073/pnas.1302277110

Nadel, D., Filin, S., Rosenberg, D., \& Miller, V. 2015, Prehistoric bedrock features: recent advances in 3D characterization and geometrical analyses. Journal of Archaeological Science, 53: 331-334. doi:10.1016/j.jas.2014.10.029

Nadel, D., Grinburg, U., Boaretto, E., \& Werker, E. 2006, Wooden objects from Ohalo II (23,000 cal BP), Jordan Valley, Israel. Journal of Human Evolution, 50(6): 644-662. doi:10.1016/j.jhevol.2005.12.010

Nadel, D., Lambert, A., Bosset, G., Bocquentin, F., Rosenberg, D., Yeshurun, R., Weissbrod, L., Tsatskin, A., Bachrach, N., Bar-Matthews, M., Ayalon, A., Zaidner, Y., Beeri, R., \& Greenberg, H. 2012, The 2010 and 2011 seasons of excavation at Raqefet Cave. Journal of the Israel Prehistoric Society, 42: 35-73. URL: http://www.jstor.org/stable/23388468

Nadel, D., \& Lengyel, G. 2009, Human-made bedrock holes (mortars and cupmarks) as a Late Natufian social phenomenon. Archaeology, Ethnology and Anthropology of Eurasia, 37(2): 37-48. doi:10.1016/j.aeae.2009.08.012

Nadel D., Lengyel, G., Bocquentin, F., Tsatskin, A., Rosenberg, D., Yeshurun, R., Bar-Oz, G., Bar-Yosef Mayer, D.E., Beeri, R., Conyers, L., Filin, S., Hershkovitz, I., Kurzawska, A., \& Weissbrod, L. 2008, The Late Natufian at Raqefet Cave: The 2006 excavation season. Journal of the Israel Prehistoric Society, 38: 59-131.

URL: http://www.jstor.org/stable/23388467 
Nadel, D., Lengyel, Gy., Cabellos Panades, T., Bocquentin, F., Rosenberg, D., Yeshurun, R., Brown-Goodman, R., Tsatskin, A., Bar-Oz, G., \& Filin, S. 2009a, The Raqefet Cave 2008 excavation season. Journal of the Israel Prehistoric Society, 39: 21-61. URL: http://www.jstor.org/stable/23386508

Nadel, D., \& Rosenberg, D. 2010, New insights into Late Natufian bedrock features (mortars and cupmarks). Eurasian Prehistory, 7(1): 65-87.

Nadel, D. \& Rosenberg, D. 2011, Late Natufian Nahal Oren and its satellite sites: some regional and ceremonial aspects. Before Farming, 3: 1-16. doi:10.3828/bfarm.2011.3.1

Nadel, D. \& Rosenberg, D. 2013, Huzuk Musa. In: Natufian Foragers in the Levant: Terminal Pleistocene Social Changes in Western Asia. Proceedings of the 2nd Natufian Conference, Paris, (Bar-Yosef, O., \& Valla, F.R., Eds.), International Monographs in Prehistory, Archaeological Series Vol. 19, Ann Arbor: p. 382-386.

Nadel D., D. Rosenberg, N. Shtober \& Filin, S. 2011. The Nahal Galim / Nahal Ornit Prehistoric Flint Quarries in Mt. Carmel, Israel. Eurasian Prehistory 8(1-2): 51-66.

Nadel, D., Rosenberg, D. \& Yeshurun, R. 2009. The deep and the shallow: The role of Natufian bedrock features at Rosh Zin, Central Negev, Israel. Bulletin of the American Schools of Oriental Research, 355:1-29. URL: http://www.jstor.org/stable/25609332

Noy, T. 1989, Some aspects of Natufian mortuary behaviour at Nahal Oren. In: People and Culture in Change, (Hershkovitz, I., Ed.), BAR International Series Vol. 508, Archaeopress, Oxford: p. 53-57.

Noy, T. 1991, Art and decoration of the Natufian at Nahal Oren. In: The Natufian culture in the Levant, (Bar-Yosef, O., \& Valla, F.R., Eds.), Archaeological Series 1. International Monographs in Prehistory, Ann Arbor: p. 557-568.

Noy, T., \& Higgs, E.S. 1971, Raqefet Cave. Israel Exploration Journal, 21(4): 225-226. URL: http://www.jstor.org/stable/27925296

Perrot, J. 1966, Le gisement Natoufien de Mallaha (Eynan), Israël. L’Anthropologie, 70: 437483. (In French) ("The Natufian Deposit of Mallaha (Eynan), Israel).

Perrot, J., \& Ladiray, D. 1988, Les sépultures. In: Les hommes de Mallaha, (Eynan) Israël, (Perrot, J., Ladiray, D., \& Solivérès-Masséi, O., Eds.), Cahier du Centre de Recherche Français de Jérusalem 7. Association Paléorient, Paris: p. 1-106. (In French) (The tombs)

Power, R.C., Rosen, A.M., \& Nadel, D. 2014, The economic and ritual utilization of plants at the Raqefet Cave Natufian site: the evidence from phytoliths. Journal of Anthropological Archaeology, 33:49-65. doi:10.1016/j.jaa.2013.11.002

Rabinovich, R., \& Nadel, D. 1994-5, Bone tools from Ohalo II - a morphological and functional study. Journal of the Israel Prehistoric Society, 26: 32-62. URL: http://www.jstor.org/stable/23380043

Richter, T., Bode, L., House, M., Iversen, R., Otaegui, A.A., Saehle, I., Thaarup, G., Tvede, M.-L., \& Yeomans, L. 2012, Excavations at the Late Epipalaeolithic site of Shubayqa 1: Preliminary report on the first season. Neo-Lithics, 12(2): 3-13.

Rosenberg, D., Groman-Yaroslavski, I., Winter, H., Yeshurun, R., Zertal, A., BrownGoodman R. \& Nadel, D. 2010, Huzuq Musa - A Final Epipalaeolithic / PPNA site in the Jordan Valley. Paléorient, 36(2): 189-204.

URL: http://www.jstor.org/stable/41496908 
Rosenberg, D., Kaufman, D., Yeshurun, R. \& Weinstein-Evron, M. 2012, The broken record: The Natufian groundstone assemblage from el-Wad Terrace (Mount Carmel, Israel) Attributes and their interpretation. Journal of Eurasian Prehistory, 9(1-2): 93-128.

Rosenberg, D., \& Nadel, D. 2014, The sounds of pounding: Boulder mortars and their significance to Natufian burial customs. Current Anthropology, 55(6): 784-812 (+comments and reply). doi:10.1086/679287

Shaham, D., \& Belfer-Cohen, A. 2013, Incised slabs from Hayonim cave: a methodological case study for reading Natufian art. In: Stone Tools in Transition: From HunterGatherers to Farming Societies in the Near East, (Borrell, F., Ibáňez, J.J., \& Molist, M., Eds.), Universitat Autònoma de Barcelona. Servei de Publicacions, Bellaterra, Barcelona: p. 407-419.

Stekelis, M. \& Yizraely, T. 1963, Excavation at Nahal Oren. Israel Exploration Journal, 13: $1-12$.

Tixier, J. 1974, Poinçon décoré du Paléolithique SupérieuràKsar 'Aqil (Liban). Paléorient, 2(1): 187-192. doi:10.3406/paleo.1974.4183

Valla, F.R. 1995, The first settled societies - Natufian (12,500-10,200 BP). In: The Archaeology of Society in the Holy Land (Levy, T.E., Ed.), Leicester University Press, London and Washington: p. 169-187.

Valla, F.R. 2012, Manifestations symboliques. In: Les Fouilles de la Terrasse d'Hayonim (Israel), 1980-1981 et 1985-1989, (Valla, F.R., Ed.), Mémoires et Travaux du Centre de Recherche Français à Jérusalem, De Boccard, Paris: p. 383-391. (In French) (Symbolic expressions).

Valla, F.R., Khalaily, H., Valladas, H., Tisnerat-Laborde, N., Samuelian, N., Bocquentin, F., Rabinovich, R., Bridault, A., Simmons, T., Le Dosseur, G., Rosen, A.M., Dubreuil L., Bar-Yosef Mayer, D.E., \& Belfer-Cohen, A. 2004, Les fouilles de Mallaha en 2000 et 2001: 3ème rapport préliminaire. Journal of the Israel Prehistoric Society, 34: 49-244. (In French) (Mallaha excavations in 2000 and 2001: third preliminary report). URL: http://www.jstor.org/stable/23389905

Weinstein-Evron, M. 1998, Early Natufian el-Wad Revisited. Etudes et recherches archéologiques de l'Université de Liège 77, Liège, 265 p.

Weinstein-Evron, M. 2009, Archaeology in the Archives: Unveiling the Natufian Culture of Mount Carmel, American School of Prehistoric Research Monograph Series, Brill, Boston, 148 p.

Weinstein-Evron, M., \& Belfer-Cohen, A. 1993, Natufian figurines from the new excavations of the El-Wad Cave, Mt. Carmel, Israel. Rock Art Research, 10(2): 102-106.

Weinstein-Evron, M., Kaufman, D., \& Yeshurun, R. 2013. Spatial organization of Natufian el-Wad through time: Combining the results of past and present excavations. In: Natufian Foragers in the Levant: Terminal Pleistocene Social Changes in Western Asia. Proceedings of the 2nd Natufian Conference, Paris, (Bar-Yosef, O., \& Valla, F.R., Eds.), International Monographs in Prehistory, Archaeological Series Vol. 19, Ann Arbor: p. 88-106.

Wright ,G.A. 1978, Social differentiation in the early Natufian. In: Social Archaeology, Beyond Subsistence and Dating, (Redman, C., Berman, M.J., Curtin, E.V., Langhorne, W.T., Versaggi, N.M. \& Wanser, J.C., Eds.), Academic Press, New York: p. 201-223. 
Wright, K. 1991, The origins and development of ground stone assemblages in late Pleistocene Southwest Asia. Paléorient, 17(1): 19-45. doi:10.3406/paleo.1991.4537

Wright, K. 1994, Ground stone tools and hunter-gatherer subsistence in southwest Asia: Implication for the transition to farming. American Antiquity, 59(2): 238-263. doi:10.2307/281929 